\title{
Consistency of Cone Production in Individual Red Pine
}

\author{
by
}

W.M. Stiell ${ }^{1}$

\section{Abstract}

A plantation of red pine (Pinus resinosa Ait.) produced heavy cone crops in 1970 and 1984. Established at $6.5 \times 6.5 \mathrm{~m}$, the stand was 18 -years old in 1970 and still open-grown; crowns were closed before 1984. Cone production at the two dates was compared for 28 trees. While total production was similar for 1970 and 1984, distribution within the sample differed. Although $18 \%$ of the trees maintained their rank in 1984 , some large changes in production ranking took place from one crop to the next. Despite a tendency at both dates for crop size to increase with current dbh, exceptions were evident and the largest trees did not necessarily bear the most cones. Crop size in 1970 was the variable most closely associated with 1984 crop size and was significantly correlated with it independently of $1984 \mathrm{dbh}$. High cone production did not seem to depress tree growth, based on a comparison of 1970-72 basal area increment of more versus less prolific cone bearers. Before a stand has borne its first good cone crop, expectations for highest yields would have to be based on tree size. For subsequent crops, previous production by individuals would be the best guide. The two top cone bearers far surpassed all others in both crop years and would be the first individuals selected for seed trees in a seed production area.

\section{Résumé}

Une plantation de pins rouges (Pinus resinosa Ait.) a produit de grandes quantités de cônes en 1970 et 1984 . Établie à un espacement de $6,5 \times 6,5 \mathrm{~m}$, la plantation avait 18 ans en 1970, et chaque arbre croissait encore comme étant situé en milieu ouvert. Cependant, le couvert s'est refermé avant 1984 . On a comparé la production de cônes des deux années pour 28 arbres. Tandis que la production totale était comparable en 1970 et 1984, la distribution de production de chaque échantillon a changé. Même si $18 \%$ des arbres ont maintenu leur rang productif en 1984, des changements substantiels se sont produits d'une récolte à l'autre. En dépit du fait que la taille de la récolte des deux années tendait a augmenter avec le dhp, de nombreuses exceptions ont pu être mises en évidence. Les arbres les plus larges n'ont pas nécessairement produit les plus grands nombres de cônes. La taille de la récolte en 1970 était la variable la plus fortement associée avec celle de 1984. Cette corrélation était très significative même si le dhp en 1984 ne l'était pas. La très grande production de cônes ne semble pas avoir diminuée la croissance des arbres. Cette constatation est basée sur une comparaison de croissance en surface terrière de 1970 à 1972 entre des arbres produisant de faibles quantités de cônes et ceux qui sont de bons producteurs. Avant qu'un peuplement produise sa première génération de cônes, la prédiction de grandes récoltes doit être basée sur la taille de l'arbre. Pour les récoltes subséquentes, les productions précédentes de chaque individu constituent le meilleur guide. Les deux meilleurs producteurs de cônes ont surpassé de loin tous les autres arbres au cours des deux années et devraient être les premiers individus sélectionnés comme arbres semenciers dans une aire de production de graines.

\section{Introduction}

Seed-bearing capacity is an important consideration in selecting trees for seed production, whether for artificial reproduction or seed-tree regeneration silviculture (Matthews 1962, Smith 1986). The ability of individuals to bear fruit prolifically and consistently provides for high yields from seed production areas and seed orchards. Plantations of their

\footnotetext{
Petawawa National Forestry Institute, Chalk River, Ontario K0J 1J0 ${ }^{2}$ Yeatman, C.W., pers. comm.

3Conzet, G.M. 1913. Unpub. thesis, cited by Rudolf 1957.

${ }^{4}$ Yeatman, C.W. op. cit.
}

progeny will also bear good seed crops since fruitfulness appears to be heritable (Rudolf et al. 1974). Identification of productive individuals at an early age is therefore well worthwhile, allowing early stimulation of their growth by tending.

Several published summaries of the flowering and fruiting habits of red pine are available (e.g. Fowells 1965, Fowler and Lester 1970, Krugman and Jenkinson 1974, and Stiell 1978). However one aspect of red pine fruiting on which little has been reported is the crop-to-crop uniformity of production by individuals. The observation has been made that most trees of that species "flower constantly with regard to the particular environment in which they are growing", with a few trees consistently 
Table 1. 1970 and 1984 cone crops, ranked by size of 1970 crop

\begin{tabular}{|c|c|c|c|c|c|c|c|c|c|c|c|}
\hline \multirow{3}{*}{$\begin{array}{l}\text { Tree } \\
\text { No. }\end{array}$} & \multicolumn{4}{|c|}{1970 Crop } & \multicolumn{4}{|c|}{1984 Crop } & & & . \\
\hline & \multirow{2}{*}{$\begin{array}{l}\text { Dbh } \\
\text { (cm) }\end{array}$} & \multirow{2}{*}{$\begin{array}{l}\text { Total } \\
\text { cones }\end{array}$} & \multirow[b]{2}{*}{ Rank } & \multirow{2}{*}{$\begin{array}{l}\% \text { of } \\
\text { Total } \\
\text { crop }\end{array}$} & \multirow{2}{*}{$\begin{array}{l}\text { Dbh } \\
\text { (cm) }\end{array}$} & \multirow{2}{*}{$\begin{array}{l}\text { Total } \\
\text { cones }\end{array}$} & \multicolumn{2}{|c|}{ Rank } & \multicolumn{3}{|c|}{ Mean } \\
\hline & & & & & & & Actual & Change & Cones & Rank & Category \\
\hline 49 & 23.4 & 942 & 2 & 9.0 & 40.5 & 677 & 2 & 0 & 810 & 2 & 1 \\
\hline 95 & 21.2 & 717 & 3 & 6.8 & 35.8 & 386 & 12 & -9 & 552 & 6 & 2 \\
\hline 62 & 20.5 & 628 & 4 & 6.0 & 34.4 & 546 & 8 & -4 & 587 & 4 & 2 \\
\hline 29 & 22.0 & 565 & 7 & 5.4 & 36.9 & 431 & 10 & -3 & 498 & 8 & 3 \\
\hline 91 & 22.2 & 542 & 8 & 5.2 & 35.5 & 381 & 13 & -5 & 462 & 10 & 3 \\
\hline 45 & 19.6 & 469 & 9 & 4.5 & 35.2 & 392 & 11 & -2 & 430 & 12 & 3 \\
\hline 9 & 20.5 & 453 & 10 & 4.3 & 36.3 & 671 & 3 & +7 & 562 & 5 & 2 \\
\hline 7 & 22.4 & 451 & 11 & 4.3 & 35.8 & 141 & 25 & -14 & 296 & 15 & 3 \\
\hline 8 & 24.6 & 438 & 12 & 4.2 & 37.9 & 289 & 16 & -4 & 364 & 13 & 3 \\
\hline 28 & 25.0 & 400 & 13 & 3.8 & 40.0 & 575 & 7 & +6 & 488 & 9 & 3 \\
\hline 6 & 17.5 & 225 & 19 & 2.1 & 30.0 & 191 & 23 & -4 & 208 & 21 & 3 \\
\hline 26 & 21.0 & 207 & 20 & 2.0 & 33.5 & 221 & 21 & -1 & 214 & 20 & 3 \\
\hline 4 & 21.7 & 190 & 21 & 1.8 & 33.8 & 225 & 20 & +1 & 208 & 21 & 3 \\
\hline 57 & 16.0 & 140 & 22 & 1.3 & 34.8 & 579 & 6 & +16 & 360 & 14 & 2 \\
\hline 37 & 17.7 & 116 & 23 & 1.1 & 33.7 & 251 & 19 & +4 & 184 & 24 & 3 \\
\hline 55 & 18.2 & 110 & 24 & 1.1 & 33.7 & 157 & 24 & 0 & 134 & 25 & 3 \\
\hline 39 & 16.0 & 106 & 25 & 1.0 & 29.1 & 296 & 15 & +10 & 201 & 23 & 3 \\
\hline 59 & 14.2 & 30 & 26 & 0.3 & 29.5 & 40 & 26 & 0 & 35 & 26 & 4 \\
\hline 3 & 15.6 & 8 & 27 & $<0.1$ & 29.7 & 0 & 28 & -1 & 4 & 28 & 4 \\
\hline 87 & 11.7 & 3 & 28 & $<0.1$ & 30.0 & 19 & 27 & +1 & 11 & 27 & 4 \\
\hline \multirow[t]{2}{*}{$n=28$} & $\overline{\text { Sum }}$ & 10486 & & & & 10082 & & & & & \\
\hline & Mean & 374 & & & & 360 & & & & & \\
\hline
\end{tabular}

producing no female strobili2. It has been said also that some red pine are consistently good or consistently poor cone producers $^{3}$, but no specific information is available on that important point. Red pine is subject to numerous agents damaging to seed production (Rudolf 1957). In central and southern Ontario the periodicity of good cone crops is largely constrained by populations of flower and cone insects (Lyons 1960), and unseasonable frosts ${ }^{4}$, so that individual tree performance can only approach its potential when these constraints are at a minimum.

This report deals with the 1970 and 1984 cone crops borne in a young plantation of red pine established near Chalk River, Ontario $\left(46^{\circ} 00^{\prime} \mathrm{N}\right.$ lat., $77^{\circ} 26^{\prime} \mathrm{W}$ long). It compares production by the stand and the individual trees at the two dates, and examines the relation of tree crop size to stem diameter and to subsequent diameter growth.

\section{Methods and Materials}

In 1970 an 18-year-old plantation of red pine, established as a spacing trial, produced its first heavy cone crop. Cone counts were made in each of six spacings, ranging from $1.2 \times$ $1.2 \mathrm{~m}$ to $6.5 \times 6.5 \mathrm{~m}$. Counts were made on mechanically selected, numbered trees in permanent sample plots, in each case distributed over the range of stem diameters represented. Mature and aborted cones damaged by the rusty cone moth (Dioryctria disclusa Heinr.) were tallied separately. Counting involved climbing each sample tree and examining every branch. Diameter at breast height (dbh) was measured on all sample trees. Other details of field procedures and of compilation and analysis were described by Stiell (1971).

What was considered a medium cone crop occurred in 1978, but no counts were made. In 1984 a heavy cone crop was observed: cones were counted, and dbh measured, on the same trees tallied in 1970 on the plot at the $6.5 \times 6.5 \mathrm{~m}$ spacing. By far the greatest cone production per tree and per hectare had been found at that spacing in 1970. Twenty-eight trees were examined, a $29 \%$ sample of those present on the plot. The permanent plots were on a 5-year schedule of crown and stem remeasurement for mensurational purposes, and the closest such dates to the 1970 and 1984 cone crops were 1972 and 1982.

Regression analysis was used to relate crop size to tree size at both dates, and to relate 1984 crop size to $1970 \mathrm{crop}$ size. The sum of both mature and aborted cones was used as more closely approximating potential cone production. Transformed data (the square root of cone numbers) were used in the analysis. Changes in actual crop size for individual trees, and in their ranking, were examined also. Because heavy seed production can divert consumption of carbohydrates from foliage production, resulting in markedly reduced annual ring width (Daniel et al. 1979), relations of 1970 crop size to $1970-72$ basal area growth were analyzed.

\section{Results and Discussion}

Stand conditions

In 1970 the stand was essentially open-grown with live crowns extending almost to the ground, and with no lateral 


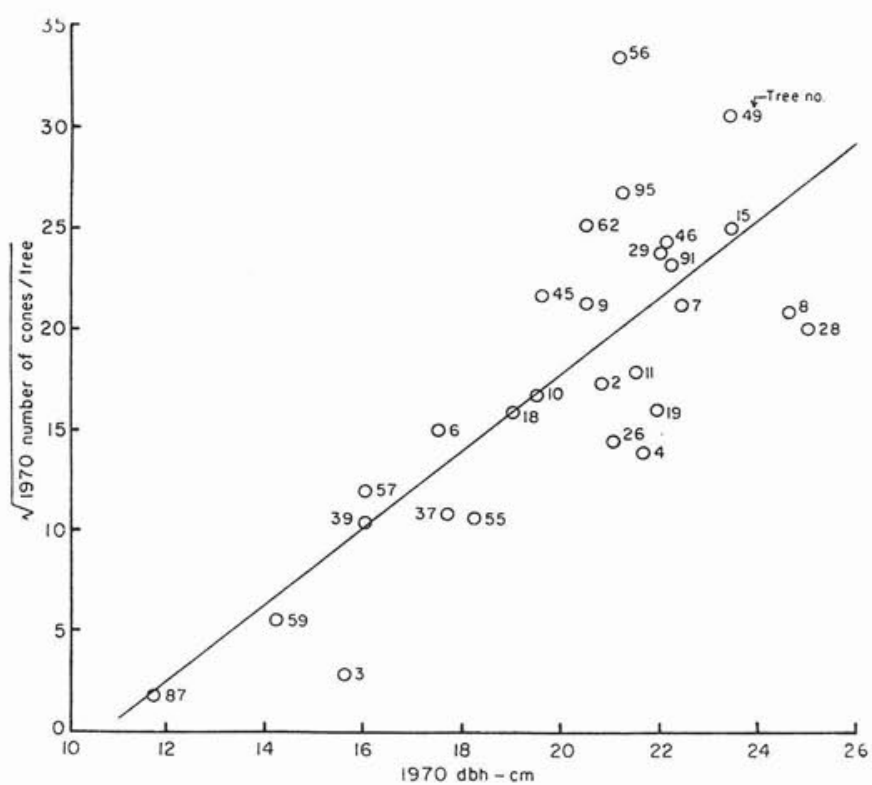

Figure 1. Relation cone crop to dbh, 1970.

contact between them. Stand closure occurred some time before 1984. By then the base of the live crowns was over $4 \mathrm{~m}$ above ground level, and crowns were both longer and wider than in 1970. No trees had died since planting.

\section{Cone crops per tree}

Table 1 shows a listing of cone crops borne by individual trees, as ranked by 1970 crop size, together with dbh, for both dates. Total cones produced were very similar for the two crops: 10486 in 1970, and 10082 in 1984. Proportions of aborted cones were $11.9 \%$ and $9.1 \%$, respectively.

High variation in crop size between trees is evident at both dates. Generally, the range of production diminished in the second crop year, with the top 12 cone bearers in 1970 showing fewer numbers of cones in 1984, while the remaining

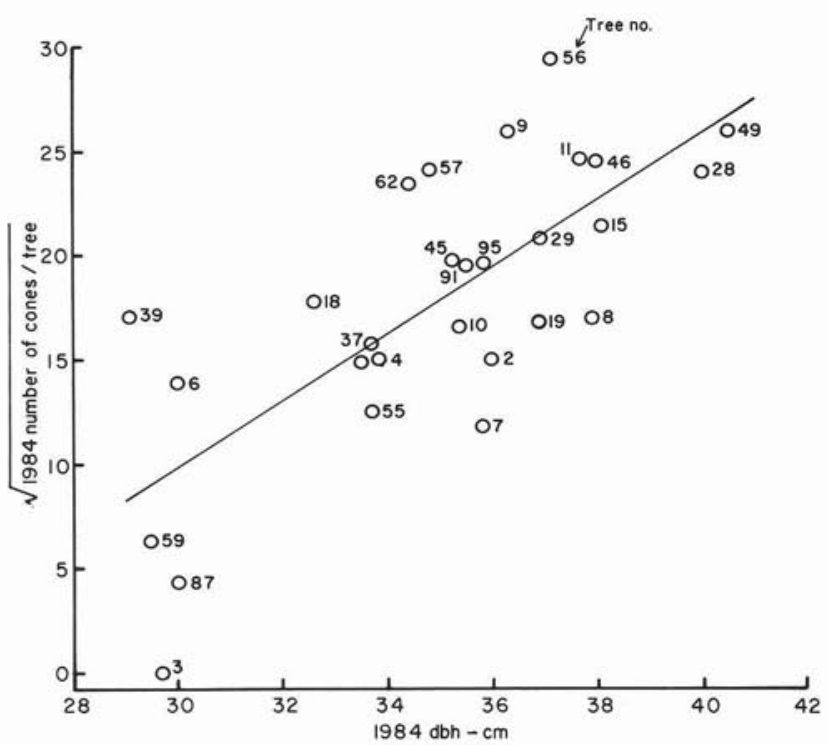

Figure 2. Relation cone crop to dbh, 1984.

16 trees increased their yield. About half the trees showed a change in rank between the two crop years of three places or less (Table 1). However some very large changes in rank took place, positively for tree nos. 11 and 39 (gain of 10 places each) and for no. 57, which gained 16 places. Tree no. 7 lost 14 places and no. 95 lost 9 .

The pattern of rank change seems to indicate four categories of cone yield behaviour (last column in Table 1):

Category 1 - heavy yields 5 , produced in both crop years, only two trees

Category 2 - heavy yields, ranking in the top five or six positions, produced in one crop year but not in the other. This included one-quarter of all trees.

Table 2. Statistics for cone crop regressions $\left(Y=b_{0}+b_{1} X_{1}\right.$ and $\left.Y=b_{0}+b_{1} X_{1}+b_{2} X_{11}\right)$.

A. $Y_{1}=\sqrt{1984 \text { cone numbers/tree }}$

(1) $X_{1}=\sqrt{1970 \text { cone numbers/tree }}$

(2) $X_{2}=1970$ tree $d b h$

(3) $X_{3}=1984$ tree $d b h$

(4) $X_{1}$ and $X_{3}$

$b_{0} \quad b_{1}$

\section{$b_{2}$}

$\begin{array}{rr}5.25022 & 0.70383 \\ -8.20052 & 1.29732 \\ -38.0440 & 1.59837 \\ -11.8725 & 0.52369\end{array}$

$-20.4337$

0.00822

0.0001134

-
$\overline{-}$
0.582
-
-

0.370

0.535

0.679

0.610

13.8
$\mathbf{F}^{\star}$

48.48

15.28

29.94

26.48

40.69

(6) $X=\sqrt{1970 \text { cone numbers } / \text { tree }}$

( ${ }^{*} 1$ and $26 \mathrm{df}$; all values significant at $\mathrm{P}>0.01$ )

D. Coefficients of

\begin{tabular}{lrr} 
Equation 4 & See (\%) & \multicolumn{1}{c}{ F } \\
\hline $\mathrm{b}_{0}$ & 11.67087 & 1.03 \\
$\mathrm{~b}_{1}$ & 0.15626 & 11.23 \\
$\mathrm{~b}_{2}$ & 0.39138 & 2.21
\end{tabular}

$5>600$ cones in 1970 pro-rated to $>577$ cones in 1984 ${ }^{6}$ Conzet, G.M., op. cit. 


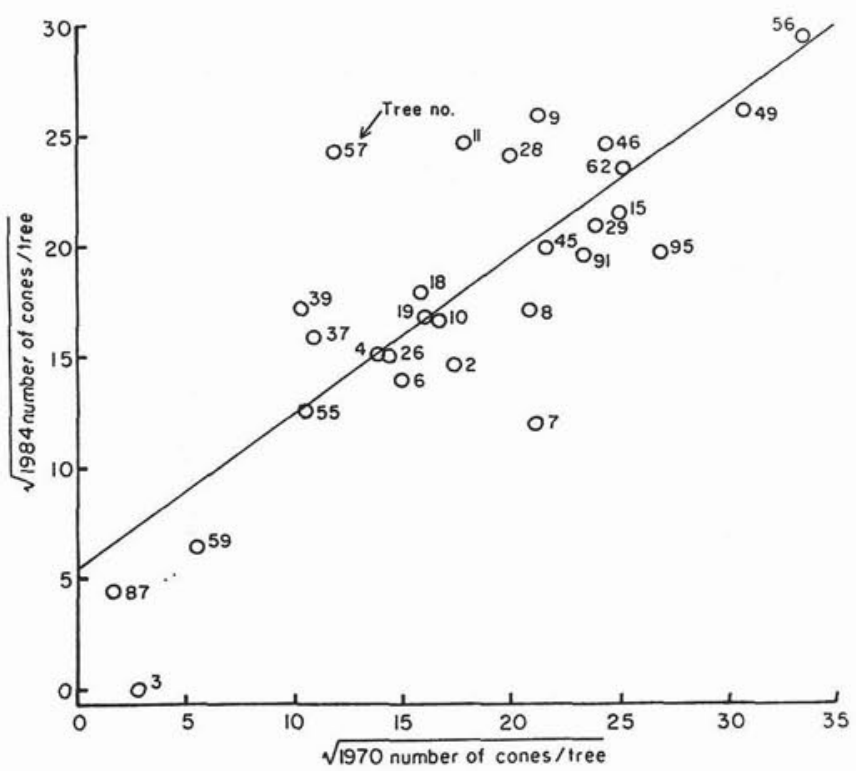

Figure 3. Relation 1984 to 1970 cone crop.

Category 3 - lower yields produced in both crop years, but covering a wide range of productivity. Over half of all trees were in this category.

Category 4 - effective non-producers in both years: three trees.

Greatest cone yields for a single tree (no. 56) were 1025 mature cones in 1970 and 792 in 1984. These exceed the 725 cones/tree reported for open-grown trees in the Lake States during good seed years 6 , but are less than those cited for Ontario in good seed years from "suitable trees" (open-grown individuals with wide spreading crowns and branches down to the ground, large-crowned dominants, and trees receiving side light and having side branches) which can produce from 1925 to 2695 cones/ tree (Ontario Ministry of Natural Resources 1977).

\section{Cone crops related to stem diameter}

Crop size increased directly with current dbh for both production years (Figures 1 and 2). Nevertheless, exceptions are evident and the largest trees did not necessarily bear the most cones. In fact, tree no. 56 , the leading cone producer at both dates, ranked only thirteenth in dbh in 1970, and seventh in 1984. The correlation of the 1984 cone crop to $1970 \mathrm{dbh}$ was weaker than that with $1984 \mathrm{dbh}$ (Equations 2 and 3 in Table 2).

Association of increasing cone numbers with larger $\mathrm{dbh}$ has been noted elsewhere for red pine (Godman 1962), and also for loblolly pine (P. taeda L.) (Pomeroy 1949).

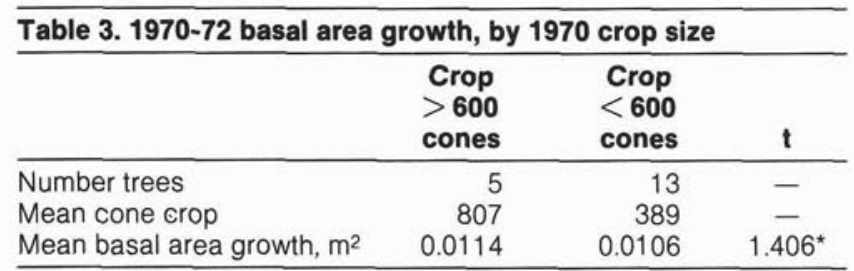

(* $16 \mathrm{df}$, not significant at $P=0.05$ )

Conzet, G.M., op. cit.
The relationship is an indirect reflection of crown size on which $\mathrm{dbh}$ and cone production both depend (Wenger and Trousdell 1958). Dbh is therefore useful for cone-crop size prediction, but to a limited extent because the variation in numbers within a diameter class is considerable.

\section{Cone crops related to past production}

The general relation between individual tree crops at the two dates is shown in Figure 3 and Table 2 (Equation 1). Of the 13 trees with above the average of 374 cones/tree in 1970, 11 remained among the 13 trees above the average of 360 cones/tree in 1984 .

The regression analysis in Table 2 shows that 1970 crop size $\left(X_{1}\right)$ is the variable most closely associated with 1984 crop size (Equation 1). Moreover, it is significantly correlated $(P>0.01)$ independently of $1984 \mathrm{dbh}\left(X_{3}\right)$. When the latter is added it does not contribute significantly to the regression $(P<0.05$, Table 2D).

The cause for higher association and lower variability between successive cone crops in an even-aged, regularly spaced plantation is the degree of fruitfulness inherent in individual trees, rather than differences in local competition or site conditions. Findings that previous cone productivity is the best indicator of future productivity for loblolly pine (Wenger and Trousdell 1958) and for shortleaf pine ( $P$. echinata Mill.) (Downs 1947) are supported for red pine by the results reported here. Nevertheless, there are many exceptions among individuals as changes in rank from 1970 to 1984 show (Table 1).

\section{Basal area growth related to cone crop}

When all trees are considered, basal area growth 1970 to 1972 showed a significant but weak direct relationship with crop size in 1970 (Table 2, Equation 6). Growth of the most prolific cone bearers in 1979, i.e. those producing more than 600 cones, was compared with those trees in the same $2-\mathrm{cm}$ dbh classes bearing less than 600 cones. No significant difference in basal area growth was found between the two groups (Table 3 ). The sample was necessarily small and confined to the three diameter classes out of eight that contained the best cone bearers.

\section{Stand cone production}

When converted to an area basis the cone counts are equivalent to 32304 mature cones/ac (70 823/ha) for 1970 (Stiell 1971), and to 32028 cones/ac (70141/ha) for 1984 . These yields are probably closer to the "bumper" crops said to occur only every 10 or 12 years than to the "good" crops produced at intervals of three to seven years ${ }^{7}$. On the other hand, size of the 1970 and 1984 crops reported here is very close to that found by Overton and Johnson (1984) in a young red pine plantation in Wisconsin, spaced at 25 to $30 \mathrm{ft}$ ( 7.6 to $9.1 \mathrm{~m})$. From their observations of this and other stands, they concluded that open-grown plantations, provided they are maintained in that condition, will bear heavy crops on a more regular basis than the "good" crops in natural stands referred to above.

The ability of the $6.5 \times 6.5 \mathrm{~m}$ stand to produce as many cones in 1984, despite canopy closure, as in the open-grown conditions of 1970 , is probably due in part to the larger crowns prevailing at the later date, and hence larger cone-bearing surfaces. The smaller trees, which generally increased their yields at the second crop, would have enlarged their crowns prior to closure. In addition, increasing age would normally be accompanied by greater potential for cone production in this young stand when more of the trees' energy is diverted from 
vegetative growth to reproduction (United States Department of Agriculture 1948).

\section{Conclusions}

1. Before a stand has borne its first good cone crop, expectations for highest yields would have to be based on tree size. For the second crop, previous production by individuals would be the best guide. Subsequently, averaging successive tree yields, as in Table 1, should help even out results and increase reliability of future crop estimates. Absolute size of the crop is too subject to depredations by cone insects, etc., to allow accurate predictions, and relative cone production based on previous behaviour would be the most realistic approach.

2. If this plantation were to be developed as a seed production area, trees in Categories 1 and 2 would be the logical choice for seed trees, and should now be released to allow maintenance or increase of crown size (Rudolf 1959). About $40 \%$ of the stand should be removed for this purpose, all from lower yielding trees in categories 3 and 4 . The two Category 1 trees, whose high yields far surpassed those of the rest of the study trees, and had a combined production of more than $15 \%$ of the stand total, might qualify as the "consistently good cone producers" referred to in the Introduction.

3. Tree no. 56 shows the greatest promise: the leading cone producer in both crop years with an average yield $23 \%$ greater than the next in rank, its diameter growth was not unduly reduced by high cone production.

\section{Acknowledgments}

The following contributions to this study are acknowledged: Mr. D.J. McGuire directed and took part in the field work, supervised compilation, and drafted the figures; Dr. R.M. Newnham and Mr. D.A. MacLeod recommended statistical procedures; Mr. C.F. Robinson performed the computer analysis.

\section{References}

Daniel, T.W., J.A. Helms and F.S. Baker. 1979. Principles of Silviculture. McGraw-Hill Book Co., New York. 2nd ed. 500 pp.

Downs, AA. 1947. Choosing pine seed trees. J. For. 45:593-594.

Fowells, H.A. (Comp.) 1965. Silvics of Forest Trees of the United States. USDA For. Serv., Washington, D.C. Agric. Handb. 271. $762 \mathrm{pp}$.
Fowler, D.P. and D.T. Lester. 1970. The genetics of red pine. USDA For. Serv., Washington, D.C. Res. Pap. W0-8. 13 pp.

Godman, R.M. 1962. Red pine cone production stimulated by heavy thinning. USDA For. Serv., Lake States For. Exp. Stn., St. Paul, Minn. Tech. Note 628. 2 pp.

Krugman, S.L. and J.L. Jenkinson. 1974. Pinus L. Pine. Pages 598-638 in Schopmeyer, C.S. (Tech. Coord.) Seeds of Woody Plants in the United States. USDA For. Serv., Washington, D.C. Agric. Handb. 450.883 pp.

Lyons, L.A. 1960. Insects affecting seed production in red pine Pages 144-148 in Horton, K.W. and G.H.D. Bedell. White and Red Pine Ecology, Silviculture and Management. Can. Dep. North. Aff. Natl. Resour., For. Br., Ottawa, Ont. Bull. 124. 185 pp.

Matthews, J.D. 1962. Seed selection and tree breeding in Britain. For. Comm., 8th Br. Commonw. For. Conf. 1962, East Africa. 5 pp.

Ontario Ministry of Natural Resources. 1977. Manual of seed collecting. For. Res. Branch, Toronto, Ont. Rev. 26 pp.

Overton, R.P. and L.C. Johnson. 1984. Red pine - potential for genetic improvement and observations on cone and seed production. Proc. 29th Northeast. Tree Improv. Conf., West Va.

Pomeroy, K.B. 1949. Loblolly pine seed trees: selection, fruitfulness, and mortality. USDA For. Serv. Southeast. For. Exp. Stn., Asheville, N.C. Sta. Pap. 5. 17 pp.

Rudolf, P.O. 1957. Silvical characteristics of red pine (Pinus resinosa). USDA For. Serv., Lake States For. Exp. Stn., St. Paul, Minn. Stn. Pap. 44. 32 pp

Rudolf, P.O. 1959. Seed production areas in the Lake States. USDA For. Serv., Lake States For. Exp. Stn., St. Paul, Minn. Stn. Pap. 73. $16 \mathrm{pp}$.

Rudolf, P.O., K.W. Dorman, R.G. Hitt and A.P. Plummer. 1974. Production of genetically improved seed. Pages 53-74 in Schopmeyer, C.S., (Tech. coord.) Seeds of Woody Plants in the United States. USDA For. Serv., Washington, D.C. Agric. Handb. 450. 883 pp.

Smith, D.M. 1986. The Practice of Silviculture. John Wiley and Sons, New York. 8th ed. 572 pp.

Stiell, W.M. 1971. Comparative cone production in young red pine planted at different spacings. Dep. Environ., Can. For. Serv., Ottawa, Ont. Publ. 1306.8 pp.

Stiell, W.M. 1978. Characteristics of eastern white pine and red pine. Pages 7-50 in Cameron, D.A. (Comp.) White and Red Pine Symposium. Dep. Environ., Can. For. Serv., Sault Ste. Marie, Ont. Symp. Proc. O-P-6. 178 pp.

United States Department of Agriculture. 1948. Seed production and dispersal. Pages 9-13 in Woody-plant Seed Manual. USDA For. Serv. Washington, D.C. Misc. Publ. 654. 416 pp.

Wenger, K.F. and K.B. Trousdell. 1958. Natural regeneration of loblolly pine in the South Atlantic Coastal Plain. USDA For. Serv., Washington, D.C., Prod. Res. Rep. 13. 78 pp.

Yao, Y.N., J.A. Pitcher, J.W. Wright and P.C. Kuo. 1971. Improved red pine for Michigan. Mich. State Univ. Agric. Exp. Stn., East Lansing, Mich. Res. Rep. 146. 7 pp.

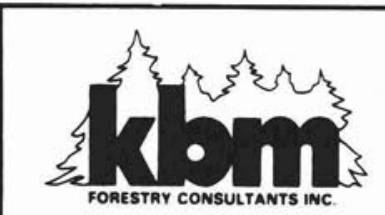

360 mooney street thunder bay, ontario P7B 5R4

$$
\begin{gathered}
\text { REFORESTATION EQUIPMENT } \\
- \text { Sales Service Parts Repair } \\
\text { REGENERATION \& SITE PREPARATION } \\
- \text { Contract Assessment Consulting } \\
\text { Tele 807-344-0811 telex 073-4522 } \\
\text { Toll free 1-800-465-3001 }
\end{gathered}
$$

\section{Woodlot Service (1978) Ltd.}

\author{
"All Matters Pertalning to Forestry"
}

\section{GORDON B. YOUNG, B.Sc.F., M.F. \\ Registered Professional Forester}

320 Maple Street

Fredericton, N.B.

Bus.: 506-458-9366

E3A 3R4 